\title{
Hydrolases (version 2019.5) in the IUPHAR/BPS Guide to Pharmacology Database
}

\author{
Stephen P.H. Alexander ${ }^{1}$, Patrick Doherty ${ }^{2}$, David Fairlie ${ }^{3}$, Christopher J. Fowler ${ }^{4}$, Christopher M. Overall ${ }^{5}$, Neil
} Rawlings $^{6}$, Christopher Southan ${ }^{7}$ and Anthony J. Turner ${ }^{8}$

1. University of Nottingham, UK

2. King's College London, UK

3. University of Queensland, Australia

4. University Hospital of Umeå, Sweden

5. University of British Columbia, Canada

6. Wellcome Trust Sanger Institute, UK

7. University of Edinburgh, Sweden

8. University of Leeds, UK

\begin{abstract}
Listed in this section are hydrolases not accumulated in other parts of the Concise Guide, such as monoacylglycerol lipase and acetylcholinesterase. Pancreatic lipase is the predominant mechanism of fat digestion in the alimentary system; its inhibition is associated with decreased fat absorption. CES 1 is present at lower levels in the gut than CES2 (P23141), but predominates in the liver, where it is responsible for the hydrolysis of many aliphatic, aromatic and steroid esters. Hormone-sensitive lipase is also a relatively nonselective esterase associated with steroid ester hydrolysis and triglyceride metabolism, particularly in adipose tissue. Endothelial lipase is secreted from endothelial cells and regulates circulating cholesterol in high density lipoproteins.
\end{abstract}

\section{Contents}

This is a citation summary for Hydrolases in the Guide to Pharmacology database (GtoPdb). It exists purely as an adjunct to the database to facilitate the recognition of citations to and from the database by citation analyzers. Readers will almost certainly want to visit the relevant sections of the database which are given here under database links.

GtoPdb is an expert-driven guide to pharmacological targets and the substances that act on them. GtoPdb is a reference work which is most usefully represented as an on-line database. As in any publication this work should be appropriately cited, and the papers it cites should also be recognized. This document provides a citation for the relevant parts of the database, and also provides a reference list for the research cited by those parts.

Please note that the database version for the citations given in GtoPdb are to the most recent preceding version in which the family or its subfamilies and targets were substantially changed. The links below are to the current version. If you need to consult the cited version, rather than the most recent version, please contact the GtoPdb curators.

\section{Database links}

Hydrolases

http://www.guidetopharmacology.org/GRAC/FamilyDisplayForward?familyld=799

Enzymes 
$\mathrm{AChE}$ (acetylcholinesterase (Cartwright blood group))

http://www.guidetopharmacology.org/GRAC/ObjectDisplayForward?objectld=2465

$\mathrm{BChE}$ (butyrylcholinesterase)

http://www.guidetopharmacology.org/GRAC/ObjectDisplayForward?objectld=2471

DAGL $\alpha($ Diacylglycerol lipase $\alpha)$

http://www.guidetopharmacology.org/GRAC/ObjectDisplayForward?objectld=1396

DAGL $\beta$ (Diacylglycerol lipase $\beta$ )

http://www.guidetopharmacology.org/GRAC/ObjectDisplayForward?objectld=1397

CES1 (carboxylesterase 1)

http://www.guidetopharmacology.org/GRAC/ObjectDisplayForward?objectld=2592

NTPDase-1 (ectonucleoside triphosphate diphosphohydrolase 1)

http://www.guidetopharmacology.org/GRAC/ObjectDisplayForward?objectld=2888

NTPDase-2(ectonucleoside triphosphate diphosphohydrolase 2)

http://www. guidetopharmacology.org/GRAC/ObjectDisplayForward?objectld=2889 epoxide hydrolase 2

http://www.guidetopharmacology.org/GRAC/ObjectDisplayForward?objectld=2970 FAAH(Fatty acid amide hydrolase)

http://www.guidetopharmacology.org/GRAC/ObjectDisplayForward?objectld=1400 Leukotriene $\mathrm{A}_{4}$ hydrolase

http://www.guidetopharmacology.org/GRAC/ObjectDisplayForward?objectld=1395 LIPE(lipase E, hormone sensitive type)

http://www.guidetopharmacology.org/GRAC/ObjectDisplayForward?objectld=2593 LIPG(lipase G, endothelial type)

http://www.guidetopharmacology.org/GRAC/ObjectDisplayForward?objectld=2591

MAGL(Monoacylglycerol lipase)

http://www.guidetopharmacology.org/GRAC/ObjectDisplayForward?objectld=1399 nudix hydrolase 7

http://www.guidetopharmacology.org/GRAC/ObjectDisplayForward?objectld=3085 O-GIcNAcase

http://www.guidetopharmacology.org/GRAC/ObjectDisplayForward?objectld=3101 PNLIP(pancreatic lipase)

http://www.guidetopharmacology.org/GRAC/ObjectDisplayForward?objectld=2590 $\mathrm{PLA}_{2}-\mathrm{G} 7$

http://www.guidetopharmacology.org/GRAC/ObjectDisplayForward?objectld=1432 SPLA $-2 \mathrm{~A}$

http://www.guidetopharmacology.org/GRAC/ObjectDisplayForward?objectld=1417

PLD2

http://www.guidetopharmacology.org/GRAC/ObjectDisplayForward? objectld=1434

vanin 1

http://www.guidetopharmacology.org/GRAC/ObjectDisplayForward?objectld=3063

\section{References}

1. Aaltonen N, Savinainen JR, Ribas CR, Rönkkö J, Kuusisto A, Korhonen J, Navia-Paldanius D, Häyrinen J, Takabe P and Käsnänen $\mathrm{H}$ et al.. (2013) Piperazine and piperidine triazole ureas as ultrapotent and highly selective inhibitors of monoacylglycerol lipase. Chem. Biol. 20: 379-90 [PMID:23521796]

2. Ahn K, Johnson DS, Fitzgerald LR, Liimatta M, Arendse A, Stevenson T, Lund ET, Nugent RA, Nomanbhoy TK and Alexander JP et al.. (2007) Novel mechanistic class of fatty acid amide hydrolase inhibitors with remarkable selectivity. Biochemistry 46: 13019-30 [PMID:17949010]

3. Ahn K, Johnson DS, Mileni M, Beidler D, Long JZ, McKinney MK, Weerapana E, Sadagopan N, Liimatta M and Smith SE et al.. (2009) Discovery and characterization of a highly selective FAAH inhibitor that reduces inflammatory pain. Chem. Biol. 16: 411-20 [PMID:19389627]

4. Antonioli L, Pacher P, Vizi ES and Haskó G. (2013) CD39 and CD73 in immunity and inflammation.Trends Mol Med 19: 355-67 [PMID:23601906]

5. Aurrand-Lions M, Galland F, Bazin H, Zakharyev VM, Imhof BA and Naquet P. (1996) Vanin-1, a novel GPI-linked perivascular molecule involved in thymus homing. Immunity 5: 391-405 [PMID:8934567]

6. Baggelaar MP, Chameau PJ, Kantae V, Hummel J, Hsu KL, Janssen F, van der Wel T, Soethoudt M, 
Deng $\mathrm{H}$ and den Dulk $\mathrm{H}$ et al.. (2015) Highly Selective, Reversible Inhibitor Identified by Comparative Chemoproteomics Modulates Diacylglycerol Lipase Activity in Neurons. J. Am. Chem. Soc. 137: 8851-7 [PMID:26083464]

7. Baqi Y, Lee SY, Iqbal J, Ripphausen P, Lehr A, Scheiff AB, Zimmermann H, Bajorath J and Müller CE. (2010) Development of potent and selective inhibitors of ecto-5'-nucleotidase based on an anthraquinone scaffold. J. Med. Chem. 53: 2076-86 [PMID:20146483]

8. Bastid J, Cottalorda-Regairaz A, Alberici G, Bonnefoy N, Eliaou JF and Bensussan A. (2013) ENTPD1/CD39 is a promising therapeutic target in oncology. Oncogene 32: 1743-51 [PMID:22751118]

9. Berruyer C, Martin FM, Castellano R, Macone A, Malergue F, Garrido-Urbani S, Millet V, Imbert J, Duprè S and Pitari $G$ et al.. (2004) Vanin-1-/- mice exhibit a glutathione-mediated tissue resistance to oxidative stress. Mol. Cell. Biol. 24: 7214-24 [PMID:15282320]

10. Berruyer C, Pouyet L, Millet V, Martin FM, LeGoffic A, Canonici A, Garcia S, Bagnis C, Naquet P and Galland F. (2006) Vanin-1 licenses inflammatory mediator production by gut epithelial cells and controls colitis by antagonizing peroxisome proliferator-activated receptor gamma activity. J. Exp. Med. 203: 281727 [PMID:17145956]

11. Bisogno T, Howell F, Williams G, Minassi A, Cascio MG, Ligresti A, Matias I, Schiano-Moriello A, Paul P and Williams EJ et al.. (2003) Cloning of the first sn1-DAG lipases points to the spatial and temporal regulation of endocannabinoid signaling in the brain. J. Cell Biol. 163: 463-8 [PMID:14610053]

12. Blackie JA, Bloomer JC, Brown MJ, Cheng HY, Hammond B, Hickey DM, Ife RJ, Leach CA, Lewis VA and Macphee $\mathrm{CH}$ et al.. (2003) The identification of clinical candidate SB-480848: a potent inhibitor of lipoprotein-associated phospholipase A2. Bioorg. Med. Chem. Lett. 13: 1067-70 [PMID:12643913]

13. Blocher R, Lamers C, Wittmann SK, Diehl O, Hanke T, Merk D, Steinhilber D, Schubert-Zsilavecz M, Kahnt AS and Proschak E. (2016) Design and synthesis of fused soluble epoxide hydrolase/peroxisome proliferator-activated receptor modulators Medchemcomm 7: 1209-1216

14. Blöcher R, Wagner KM, Gopireddy RR, Harris TR, Wu H, Barnych B, Hwang SH, Xiang YK, Proschak E and Morisseau C et al.. (2018) Orally Available Soluble Epoxide Hydrolase/Phosphodiesterase 4 Dual Inhibitor Treats Inflammatory Pain. J. Med. Chem. 61: 3541-3550 [PMID:29614224]

15. Boersma YL, Newman J, Adams TE, Cowieson N, Krippner G, Bozaoglu K and Peat TS. (2014) The structure of vanin 1: a key enzyme linking metabolic disease and inflammation. Acta Crystallogr. D Biol. Crystallogr. 70: 3320-9 [PMID:25478849]

16. Bonnard E, Poras H, Nadal X, Maldonado R, Fournié-Zaluski MC and Roques BP. (2015) Long-lasting oral analgesic effects of $\mathrm{N}$-protected aminophosphinic dual ENKephalinase inhibitors (DENKIs) in peripherally controlled pain. Pharmacol Res Perspect3: e00116 [PMID:25692029]

17. Borg-Capra Catherine Sylvia et al.. (2001) Method of screening for triacyglycerol hydrolase inhibitors. Patent number: WO2001016358.

18. Bosanac T, Burke MJ, Cook BN, DiSalvo DT, Kirrane Jr TM and Shen Y. (2018) HETEROAROMATIC COMPOUNDS AS VANIN INHIBITORS Patent number: WO2018228934.

19. Boyle NA, Talesa V, Giovannini E, Rosi G and Norton SJ. (1997) Synthesis and study of thiocarbonate derivatives of choline as potential inhibitors of acetylcholinesterase. J. Med. Chem. 40: 3009-13 [PMID:9301662]

20. Brunschweiger A, lqbal J, Umbach F, Scheiff AB, Munkonda MN, Sévigny J, Knowles AF and Müller CE. (2008) Selective nucleoside triphosphate diphosphohydrolase-2 (NTPDase2) inhibitors: nucleotide mimetics derived from uridine-5'-carboxamide. J. Med. Chem. 51: 4518-28 [PMID:18630897]

21. Bustanji Y, Issa A, Mohammed M, Hudaib M, Tawah, K, Alkhatib H, Almarsi I and Al-Khalidi B. (2010) Inhibition of hormone sensitive lipase and pancreatic lipase by Rosmarinus officinalis extract and selected phenolic constituents. Journal of Medicinal Plants Research4: 2235-2242

22. Butini S, Campiani G, Borriello M, Gemma S, Panico A, Persico M, Catalanotti B, Ros S, Brindisi M and Agnusdei $\mathrm{M}$ et al.. (2008) Exploiting protein fluctuations at the active-site gorge of human cholinesterases: further optimization of the design strategy to develop extremely potent inhibitors. J. Med. Chem. 51: 315470 [PMID:18479118]

23. Bühler KM, Huertas E, Echeverry-Alzate V, Giné E, Moltó E, Montoliu L and López-Moreno JA. (2014) Risky alcohol consumption in young people is associated with the fatty acid amide hydrolase gene polymorphism C385A and affective rating of drug pictures. Mol. Genet. Genomics 289: 279-89 [PMID:24407958]

24. Cai XY, Wang XF, Li J, Dong JN, Liu JQ, Li NP, Yun B and Xia RL. (2015) Overexpression of CD39 and high tumoral CD39(+)/CD8(+) ratio are associated with adverse prognosis in resectable gastric cancer. Int $J$ Clin Exp Pathol 8: 14757-64 [PMID:26823801]

25. Cajanus K, Holmström EJ, Wessman M, Anttila V, Kaunisto MA and Kalso E. (2016) Effect of 
endocannabinoid degradation on pain: role of FAAH polymorphisms in experimental and postoperative pain in women treated for breast cancer. Pain 157: 361-9 [PMID:26808012]

26. Canale FP, Ramello MC, Núñez N, Araujo Furlan CL, Bossio SN, Gorosito Serrán M, Tosello Boari J, Del Castillo A, Ledesma M and Sedlik C et al.. (2018) CD39 Expression Defines Cell Exhaustion in TumorInfiltrating CD8 ${ }^{+}$T Cells. Cancer Res. 78: 115-128 [PMID:29066514]

27. Cardozo MG, limura Y, Sugimoto H, Yamanishi Y and Hopfinger AJ. (1992) QSAR analyses of the substituted indanone and benzylpiperidine rings of a series of indanone-benzylpiperidine inhibitors of acetylcholinesterase. J. Med. Chem. 35: 584-9 [PMID:1738151]

28. Casimiro-Garcia A, Condon JS, Flick AC, Gopalsamy A, Kirincich SJ, Mathias JP, Strobach JW, Xiang JS, Xing LH and Wang X. (2018) Novel heterocyclic compounds as inhibitors of vanin-1 enzyme Patent number: US20180148420A1.

29. Chang JW, Niphakis MJ, Lum KM, Cognetta 3rd AB, Wang C, Matthews ML, Niessen S, Buczynski MW, Parsons LH and Cravatt BF. (2012) Highly selective inhibitors of monoacylglycerol lipase bearing a reactive group that is bioisosteric with endocannabinoid substrates. Chem. Biol. 19: 579-88 [PMID:22542104]

30. Chen X, Wang S, Wu N and Yang CS. (2004) Leukotriene A4 hydrolase as a target for cancer prevention and therapy. Curr Cancer Drug Targets 4: 267-83 [PMID:15134534]

31. Cheung J, Rudolph MJ, Burshteyn F, Cassidy MS, Gary EN, Love J, Franklin MC and Height JJ. (2012) Structures of human acetylcholinesterase in complex with pharmacologically important ligands. J. Med. Chem. 55: 10282-6 [PMID:23035744]

32. Cisar JS, Weber OD, Clapper JR, Blankman JL, Henry CL, Simon GM, Alexander JP, Jones TK, Ezekowitz RAB and O'Neill GP et al.. (2018) Identification of ABX-1431, a Selective Inhibitor of Monoacylglycerol Lipase and Clinical Candidate for Treatment of Neurological Disorders. J. Med. Chem. 61: 9062-9084 [PMID:30067909]

33. Clark JK, Cowley P, Muir AW, Palin R, Pow E, Prosser AB, Taylor R and Zhang MQ. (2002) Quaternary salts of E2020 analogues as acetylcholinesterase inhibitors for the reversal of neuromuscular block. Bioorg. Med. Chem. Lett. 12: 2565-8 [PMID:12182861]

34. Cravatt BF, Demarest K, Patricelli MP, Bracey MH, Giang DK, Martin BR and Lichtman AH. (2001) Supersensitivity to anandamide and enhanced endogenous cannabinoid signaling in mice lacking fatty acid amide hydrolase. Proc. Natl. Acad. Sci. U.S.A. 98: 9371-6 [PMID:11470906]

35. de Jong JC, Sørensen LG, Tornqvist $\mathrm{H}$ and Jacobsen P. (2004) Carbazates as potent inhibitors of hormone-sensitive lipase. Bioorg. Med. Chem. Lett. 14: 1741-4 [PMID:15026062]

36. Deng H, Kooijman S, van den Nieuwendijk AM, Ogasawara D, van der Wel T, van Dalen F, Baggelaar MP, Janssen FJ, van den Berg RJ and den Dulk H et al.. (2017) Triazole Ureas Act as Diacylglycerol Lipase Inhibitors and Prevent Fasting-Induced Refeeding. J. Med. Chem. 60: 428-440 [PMID:27992221]

37. Draheim SE, Bach NJ, Dillard RD, Berry DR, Carlson DG, Chirgadze NY, Clawson DK, Hartley LW, Johnson LM and Jones ND et al.. (1996) Indole inhibitors of human nonpancreatic secretory phospholipase A2. 3. Indole-3-glyoxamides. J. Med. Chem. 39: 5159-75 [PMID:8978844]

38. Enjyoji K, Kotani K, Thukral C, Blumel B, Sun X, Wu Y, Imai M, Friedman D, Csizmadia E and Bleibel Wet al.. (2008) Deletion of cd39/entpd1 results in hepatic insulin resistance.Diabetes 57: 2311-20 [PMID:18567823]

39. Enjyoji K, Sévigny J, Lin Y, Frenette PS, Christie PD, Esch 2nd JS, Imai M, Edelberg JM, Rayburn H and Lech M et al.. (1999) Targeted disruption of cd39/ATP diphosphohydrolase results in disordered hemostasis and thromboregulation. Nat. Med. 5: 1010-7 [PMID:10470077]

40. Fornage M, Boerwinkle E, Doris PA, Jacobs D, Liu K and Wong ND. (2004) Polymorphism of the soluble epoxide hydrolase is associated with coronary artery calcification in African-American subjects: The Coronary Artery Risk Development in Young Adults (CARDIA) study. Circulation 109: 335-9 [PMID:14732757]

41. Galland F, Malergue F, Bazin H, Mattei MG, Aurrand-Lions M, Theillet $C$ and Naquet P. (1998) Two human genes related to murine vanin-1 are located on the long arm of human chromosome 6 . Genomics 53: 203-13 [PMID:9790769]

42. Galli A, Mori F, Benini $L$ and Cacciarelli N. (1994) Acetylcholinesterase protection and the antidiisopropylfluorophosphate efficacy of E2020. Eur. J. Pharmacol. 270: 189-93 [PMID:8039548]

43. Garscha U, Romp E, Pace S, Rossi A, Temml V, Schuster D, König S, Gerstmeier J, Liening S and Werner M et al.. (2017) Pharmacological profile and efficiency in vivo of diflapolin, the first dual inhibitor of 5-lipoxygenase-activating protein and soluble epoxide hydrolase. Sci Rep 7: 9398 [PMID:28839250]

44. Gasmi L and McLennan AG. (2001) The mouse Nudt7 gene encodes a peroxisomal nudix hydrolase specific for coenzyme A and its derivatives. Biochem. J. 357: 33-8 [PMID:11415433] 
45. Gensollen T, Bourges $C$, Rihet $P$, Rostan A, Millet V, Noguchi T, Bourdon V, Sobol H, Dubuquoy $L$ and Bertin B et al.. (2013) Functional polymorphisms in the regulatory regions of the VNN1 gene are associated with susceptibility to inflammatory bowel diseases. Inflamm. Bowel Dis. 19: 2315-25 [PMID:23949622]

46. Ghafouri N, Tiger G, Razdan RK, Mahadevan A, Pertwee RG, Martin BR and Fowler CJ. (2004) Inhibition of monoacylglycerol lipase and fatty acid amide hydrolase by analogues of 2-arachidonoylglycerol. Br. J. Pharmacol. 143: 774-84 [PMID:15492019]

47. Giacobini E. (2003) Cholinesterases: new roles in brain function and in Alzheimer's disease.Neurochem. Res. 28: 515-22 [PMID:12675140]

48. Giang DK and Cravatt BF. (1997) Molecular characterization of human and mouse fatty acid amide hydrolases. Proc. Natl. Acad. Sci. U.S.A. 94: 2238-42 [PMID:9122178]

49. Goodman KB, Bury MJ, Cheung M, Cichy-Knight MA, Dowdell SE, Dunn AK, Lee D, Lieby JA, Moore ML and Scherzer DA et al.. (2009) Discovery of potent, selective sulfonylfuran urea endothelial lipase inhibitors. Bioorg. Med. Chem. Lett. 19: 27-30 [PMID:19058966]

50. Habib AM, Okorokov AL, Hill MN, Bras JT, Lee M-C, Li S, Gossage SJ, van Drimmelen M, Morena M and Houlden $\mathrm{H}$ et al.. (2019) Microdeletion in a FAAH pseudogene identified in a patient with high anandamide concentrations and pain insensitivity British Journal of Anaesthesia

51. Hammock B and Kodani S. (2017) Inhibitors for soluble epoxide hydrolase (seh) and fatty acid amide hydrolase (faah) Patent number: WO2017160861A1.

52. Hansford KA, Reid RC, Clark CI, Tyndall JD, Whitehouse MW, Guthrie T, McGeary RP, Schafer K, Martin $\mathrm{JL}$ and Fairlie DP. (2003) D-Tyrosine as a chiral precusor to potent inhibitors of human nonpancreatic secretory phospholipase A2 (Ila) with antiinflammatory activity. Chembiochem 4: 181-5 [PMID:12616631]

53. Hosohata $\mathrm{K}$, Ando $\mathrm{H}$ and Fujimura A. (2014) Early detection of renal injury using urinary vanin-1 in rats with experimental colitis. J App/ Toxico/34: 184-90 [PMID:23307618]

54. Hsu KL, Tsuboi K, Adibekian A, Pugh H, Masuda K and Cravatt BF. (2012) DAGL $\beta$ inhibition perturbs a lipid network involved in macrophage inflammatory responses. Nat. Chem. Biol. 8: 999-1007 [PMID:23103940]

55. Häusler SF, Del Barrio IM, Diessner J, Stein RG, Strohschein J, Hönig A, Dietl J and Wischhusen J. (2014) Anti-CD39 and anti-CD73 antibodies A1 and 7G2 improve targeted therapy in ovarian cancer by blocking adenosine-dependent immune evasion. Am J Transl Res6: 129-39 [PMID:24489992]

56. Imig JD and Hammock BD. (2009) Soluble epoxide hydrolase as a therapeutic target for cardiovascular diseases. Nat Rev Drug Discov8: 794-805 [PMID:19794443]

57. Jackowski S and Leonardi R. (2014) Deregulated coenzyme A, loss of metabolic flexibility and diabetes. Biochem. Soc. Trans. 42: 1118-22 [PMID:25110012]

58. Jiang X-Y, Chen T-K, Zhou J-T, He S-Y, Yang H-Y, Chen Y, Qu W, Feng F and Sun H-P. (2018) Dual GSK-3ß/AChE Inhibitors as a New Strategy for Multitargeting Anti-Alzheimer's Disease Drug Discovery ACS Med. Chem. Lett.

59. Johnson DS, Stiff C, Lazerwith SE, Kesten SR, Fay LK, Morris M, Beidler D, Liimatta MB, Smith SE and Dudley DT et al.. (2011) Discovery of PF-04457845: A Highly Potent, Orally Bioavailable, and Selective Urea FAAH Inhibitor. ACS Med Chem Lett 2: 91-96 [PMID:21666860]

60. Johnston M, Bhatt SR, Sikka S, Mercier RW, West JM, Makriyannis A, Gatley SJ and Duclos Jr RI. (2012) Assay and inhibition of diacylglycerol lipase activity. Bioorg. Med. Chem. Lett. 22: 4585-92 [PMID:22738638]

61. Kansas GS, Wood GS and Tedder TF. (1991) Expression, distribution, and biochemistry of human CD39. Role in activation-associated homotypic adhesion of lymphocytes. J. Immunol. 146: 2235-44 [PMID:1672348]

62. Kavian N, Mehlal S, Marut W, Servettaz A, Giessner C, Bourges C, Nicco C, Chéreau C, Lemaréchal H and Dutilh MF et al.. (2016) Imbalance of the Vanin-1 Pathway in Systemic Sclerosis.J. Immunol. 197: 3326-3335 [PMID:27647831]

63. Kavitha CV, Gaonkar SL, Narendra Sharath Chandra JN, Sadashiva CT and Rangappa KS. (2007) Synthesis and screening for acetylcholinesterase inhibitor activity of some novel 2-butyl-1,3-diazaspiro[4,4]non-1-en-4-ones: derivatives of irbesartan key intermediate. Bioorg. Med. Chem. 15: 7391-8 [PMID:17888667]

64. Keith JM, Apodaca R, Tichenor M, Xiao W, Jones W, Pierce J, Seierstad M, Palmer J, Webb M and Karbarz M et al.. (2012) Aryl Piperazinyl Ureas as Inhibitors of Fatty Acid Amide Hydrolase (FAAH) in Rat, Dog, and Primate. ACS Med Chem Lett 3: 823-7 [PMID:24900385]

65. Keith JM, Apodaca R, Xiao W, Seierstad M, Pattabiraman K, Wu J, Webb M, Karbarz MJ, Brown S and Wilson S et al.. (2008) Thiadiazolopiperazinyl ureas as inhibitors of fatty acid amide hydrolase.Bioorg. 
Med. Chem. Lett. 18: 4838-43 [PMID:18693015]

66. Keith JM and Liu J. (2011) Modulators of fatty acid amide hydrolase. Patent number: WO2011139951 A1.

67. Kiss LE et al.. (2010) Pharmaceutical compounds. Patent number: WO2010074588 A2.

68. Kiss LE, Ferreira HS, Beliaev A, Torrao L and Bonafacio MJ Learmonth DA.. (2011) Design, synthesis, and structure-activity relationships of 1,3,4-oxadiazol-2(3H)-ones as novel FAAH inhibitors.

MedChemComm. 2: 889-894

69. Klingler FM, Wolf M, Wittmann S, Gribbon P and Proschak E. (2016) Bacterial Expression and HTS Assessment of Soluble Epoxide Hydrolase Phosphatase. J Biomol Screen 21: 689-94 [PMID:27009944]

70. Knight MA, Hernandez D, Diede SJ, Dauwerse HG, Rafferty I, van de Leemput J, Forrest SM, Gardner RJ, Storey E and van Ommen GJ et al.. (2008) A duplication at chromosome 11q12.2-11q12.3 is associated with spinocerebellar ataxia type 20. Hum. Mol. Genet. 17: 3847-53 [PMID:18801880]

71. Knowles AF and Chiang WC. (2003) Enzymatic and transcriptional regulation of human ecto-ATPase/ENTPDase 2. Arch. Biochem. Biophys. 418: 217-27 [PMID:14522593]

72. Kodani SD, Wan D, Wagner KM, Hwang SH, Morisseau C and Hammock BD. (2018) Design and Potency of Dual Soluble Epoxide Hydrolase/Fatty Acid Amide Hydrolase Inhibitors ACS Omega 3: 14076-14086

73. Kramer JS, Woltersdorf S, Duflot T, Hiesinger K, Lillich FF, Knöll F, Wittmann SK, Klingler FM, Brunst S and Chaikuad A et al.. (2019) Discovery of the First in Vivo Active Inhibitors of the Soluble Epoxide Hydrolase Phosphatase Domain. J. Med. Chem. 62: 8443-8460 [PMID:31436984]

74. Kruse S, Mao XQ, Heinzmann A, Blattmann S, Roberts MH, Braun S, Gao PS, Forster J, Kuehr J and Hopkin JM et al.. (2000) The lle198Thr and Ala379Val variants of plasmatic PAF-acetylhydrolase impair catalytical activities and are associated with atopy and asthma. Am. J. Hum. Genet.66: 1522-30 [PMID:10733466]

75. Lavieri RR, Scott SA, Selvy PE, Kim K, Jadhav S, Morrison RD, Daniels JS, Brown HA and Lindsley CW. (2010) Design, synthesis, and biological evaluation of halogenated N-(2-(4-oxo-1-phenyl-1,3,8triazaspiro[4.5]decan-8-yl)ethyl)benzamides: discovery of an isoform-selective small molecule phospholipase D2 inhibitor. J. Med. Chem. 53: 6706-19 [PMID:20735042]

76. Lee CR, North KE, Bray MS, Fornage M, Seubert JM, Newman JW, Hammock BD, Couper DJ, Heiss G and Zeldin DC. (2006) Genetic variation in soluble epoxide hydrolase (EPHX2) and risk of coronary heart disease: The Atherosclerosis Risk in Communities (ARIC) study. Hum. Mol. Genet. 15: 1640-9 [PMID:16595607]

77. Liu Q, Huang F, Yuan X, Wang K, Zou Y, Shen J and Xu Y. (2017) Structure-Guided Discovery of Novel, Potent, and Orally Bioavailable Inhibitors of Lipoprotein-Associated Phospholipase A2. J. Med. Chem. 60: 10231-10244 [PMID:29193967]

78. Long JZ, Li W, Booker L, Burston JJ, Kinsey SG, Schlosburg JE, Pavón FJ, Serrano AM, Selley DE and Parsons LH et al.. (2009) Selective blockade of 2-arachidonoylglycerol hydrolysis produces cannabinoid behavioral effects. Nat. Chem. Biol. 5: 37-44 [PMID:19029917]

79. Long JZ, Nomura DK, Vann RE, Walentiny DM, Booker L, Jin X, Burston JJ, Sim-Selley LJ, Lichtman AH and Wiley JL et al.. (2009) Dual blockade of FAAH and MAGL identifies behavioral processes regulated by endocannabinoid crosstalk in vivo. Proc. Natl. Acad. Sci. U.S.A. 106: 20270-5 [PMID:19918051]

80. Lopez I, Arnold RS and Lambeth JD. (1998) Cloning and initial characterization of a human phospholipase D2 (hPLD2). ADP-ribosylation factor regulates hPLD2. J. Biol. Chem. 273: 12846-52 [PMID:9582313]

81. Luo W, Yu QS, Kulkarni SS, Parrish DA, Holloway HW, Tweedie D, Shafferman A, Lahiri DK, Brossi A and Greig NH. (2006) Inhibition of human acetyl- and butyrylcholinesterase by novel carbamates of (-)- and (+)-tetrahydrofurobenzofuran and methanobenzodioxepine. J. Med. Chem. 49: 2174-85 [PMID:16570913]

82. MacPhee CH, Moores KE, Boyd HF, Dhanak D, Ife RJ, Leach CA, Leake DS, Milliner KJ, Patterson RA and Suckling KE et al.. (1999) Lipoprotein-associated phospholipase A2, platelet-activating factor acetylhydrolase, generates two bioactive products during the oxidation of low-density lipoprotein: use of a novel inhibitor. Biochem. J. 338 ( Pt 2): 479-87 [PMID:10024526]

83. Mateo J, Harden TK and Boyer JL. (1999) Functional expression of a cDNA encoding a human ectoATPase. Br. J. Pharmacol. 128: 396-402 [PMID:10510450]

84. Migliore M, Habrant D, Sasso O, Albani C, Bertozzi SM, Armirotti A, Piomelli D and Scarpelli R. (2016) Potent multitarget FAAH-COX inhibitors: Design and structure-activity relationship studies. Eur J Med Chem 109: 216-37 [PMID:26774927]

85. Morisseau C and Hammock BD. (2013) Impact of soluble epoxide hydrolase and epoxyeicosanoids on human health. Annu. Rev. Pharmacol. Toxicol. 53: 37-58 [PMID:23020295]

86. Musilek K, Komloova M, Holas O, Horova A, Pohanka M, Gunn-Moore F, Dohnal V, Dolezal M and Kuca K. (2011) Mono-oxime bisquaternary acetylcholinesterase reactivators with prop-1,3-diyl linkagePreparation, in vitro screening and molecular docking. Bioorg. Med. Chem. 19: 754-62 [PMID:21215642] 
87. Naquet $P$, Pitari $G$, Duprè $S$ and Galland F. (2014) Role of the Vnn1 pantetheinase in tissue tolerance to stress. Biochem. Soc. Trans. 42: 1094-100 [PMID:25110008]

88. Newman JW, Morisseau C, Harris TR and Hammock BD. (2003) The soluble epoxide hydrolase encoded by EPXH2 is a bifunctional enzyme with novel lipid phosphate phosphatase activity. Proc. Natl. Acad. Sci. U.S.A. 100: 1558-63 [PMID:12574510]

89. Nicolet Y, Lockridge O, Masson P, Fontecilla-Camps JC and Nachon F. (2003) Crystal structure of human butyrylcholinesterase and of its complexes with substrate and products. J. Biol. Chem. 278: 41141-7 [PMID:12869558]

90. Niphakis MJ, Cognetta 3rd AB, Chang JW, Buczynski MW, Parsons LH, Byrne F, Burston JJ, Chapman V and Cravatt BF. (2013) Evaluation of NHS carbamates as a potent and selective class of endocannabinoid hydrolase inhibitors. ACS Chem Neurosci 4: 1322-32 [PMID:23731016]

91. Ogasawara D, Deng H, Viader A, Baggelaar MP, Breman A, den Dulk H, van den Nieuwendijk AM, van den Nieuwendijk AM, Soethoudt M and van der Wel T et al.. (2016) Rapid and profound rewiring of brain lipid signaling networks by acute diacylglycerol lipase inhibition. Proc. Natl. Acad. Sci. U.S.A.113: 26-33 [PMID:26668358]

92. Orning L, Krivi G and Fitzpatrick FA. (1991) Leukotriene A4 hydrolase. Inhibition by bestatin and intrinsic aminopeptidase activity establish its functional resemblance to metallohydrolase enzymes. J. Biol. Chem. 266: 1375-8 [PMID:1846352]

93. Oslund RC, Cermak N and Gelb MH. (2008) Highly specific and broadly potent inhibitors of mammalian secreted phospholipases A2. J. Med. Chem. 51: 4708-14 [PMID:18605714]

94. Penning TD, Chandrakumar NS, Chen BB, Chen HY, Desai BN, Djuric SW, Docter SH, Gasiecki AF, Haack RA and Miyashiro JM et al.. (2000) Structure-activity relationship studies on 1-[2-(4Phenylphenoxy)ethyl]pyrrolidine (SC-22716), a potent inhibitor of leukotriene A(4) (LTA(4)) hydrolase. J. Med. Chem. 43: 721-35 [PMID:10691697]

95. Pouyet L, Roisin-Bouffay C, Clément A, Millet V, Garcia S, Chasson L, Issaly N, Rostan A, Hofman P and Naquet $P$ et al.. (2010) Epithelial vanin-1 controls inflammation-driven carcinogenesis in the colitisassociated colon cancer model. Inflamm. Bowel Dis. 16: 96-104 [PMID:19572375]

96. Preininger AM, Henage LG, Oldham WM, Yoon EJ, Hamm HE and Brown HA. (2006) Direct modulation of phospholipase D activity by Gbetagamma. Mol. Pharmacol. 70: 311-8 [PMID:16638972]

97. Quattropani A, Kulkarni SS and Giri AG. (2017) Glycosidase inhibitors Patent number: WO2017144639A1.

98. Reilly SJ, Tillander V, Ofman R, Alexson SE and Hunt MC. (2008) The nudix hydrolase 7 is an Acyl-CoA diphosphatase involved in regulating peroxisomal coenzyme A homeostasis. J. Biochem. 144: 655-63 [PMID:18799520]

99. Resnick E, Bradley A, Gan J, Douangamath A, Krojer T, Sethi R, Aimon A, Amitai G, Belini D, Bennett J and Fairhead $\mathrm{M}$ et al.. (2018) Rapid covalent-probe discovery by electrophile fragment screening bioRxiv

100. Roughley S, Walls S, Hart T, Parsons R, Brough P, Graham C and Macias A. (2009) Azetidine derivatives. Patent number: WO2009109743 A1.

101. Sandanayaka V, Mamat B, Mishra RK, Winger J, Krohn M, Zhou LM, Keyvan M, Enache L, Sullins D and Onua E et al.. (2010) Discovery of 4-[(2S)-2-\{[4-(4-chlorophenoxy)phenoxy]methyl\}-1-pyrrolidinyl]butanoic acid (DG-051) as a novel leukotriene A4 hydrolase inhibitor of leukotriene B4 biosynthesis. J. Med. Chem. 53: 573-85 [PMID:19950900]

102. Santoni G, de Sousa J, de la Mora E, Dias J, Jean L, Sussman JL, Silman I, Renard PY, Brown RCD and Weik M et al.. (2018) Structure-Based Optimization of Nonquaternary Reactivators of Acetylcholinesterase Inhibited by Organophosphorus Nerve Agents. J. Med. Chem. 61: 7630-7639 [PMID:30125110]

103. Sarri E, Pardo R, Fensome-Green A and Cockcroft S. (2003) Endogenous phospholipase D2 localizes to the plasma membrane of RBL-2H3 mast cells and can be distinguished from ADP ribosylation factorstimulated phospholipase D1 activity by its specific sensitivity to oleic acid. Biochem. J. 369: 319-29 [PMID:12374567]

104. Schierle S, Flauaus C, Heitel P, Willems S, Schmidt J, Kaiser A, Weizel L, Goebel T, Kahnt AS and Geisslinger $\mathrm{G}$ et al.. (2018) Boosting Anti-Inflammatory Potency of Zafirlukast by Designed Polypharmacology. J. Med. Chem. 61: 5758-5764 [PMID:29878767]

105. Scott SA, Selvy PE, Buck JR, Cho HP, Criswell TL, Thomas AL, Armstrong MD, Arteaga CL, Lindsley CW and Brown HA. (2009) Design of isoform-selective phospholipase D inhibitors that modulate cancer cell invasiveness. Nat. Chem. Biol. 5: 108-17 [PMID:19136975]

106. Selnick HG, Hess JF, Tang C, Liu K, Schachter JB, Ballard JE, Marcus J, Klein DJ, Wang X and Pearson $\mathrm{M}$ et al.. (2019) Discovery of MK-8719, a Potent O-GlcNAcase Inhibitor as a Potential Treatment for Tauopathies. J. Med. Chem. [PMID:31487175]

107. Snyder DW, Bach NJ, Dillard RD, Draheim SE, Carlson DG, Fox N, Roehm NW, Armstrong CT, Chang 
CH and Hartley LW et al.. (1999) Pharmacology of LY315920/S-5920, [[3-(aminooxoacetyl)-2-ethyl-1(phenylmethyl)-1H-indol-4-yl]oxy] acetate, a potent and selective secretory phospholipase A2 inhibitor: A new class of anti-inflammatory drugs, SPI. J. Pharmacol. Exp. Ther. 288: 1117-24 [PMID:10027849]

108. Song J, Baek IJ, Chun CH and Jin EJ. (2018) Dysregulation of the NUDT7-PGAM1 axis is responsible for chondrocyte death during osteoarthritis pathogenesis. Nat Commun 9: 3427 [PMID:30143643]

109. Stagg J. (2012) The double-edge sword effect of anti-CD73 cancer therapy. Oncoimmunology 1: 217-218 [PMID:22720247]

110. Stsiapanava A, Samuelsson B and Haeggström JZ. (2017) Capturing LTA hydrolase in action: Insights to the chemistry and dynamics of chemotactic $\mathrm{LTB}_{4}$ synthesis. Proc. Natl. Acad. Sci. U.S.A.114: $9689-9694$ [PMID:28827365]

111. Sánchez-Muñoz F, Amezcua-Guerra LM, Macías-Palacios M, Márquez-Velasco R and Bojalil R. (2013) Vanin-1 as a potential novel biomarker for active nephritis in systemic lupus erythematosus. Lupus 22: 333-5 [PMID:23390193]

112. Taylor SJ, Soleymanzadeh F, Eldrup AB, Farrow NA, Muegge I, Kukulka A, Kabcenell AK and De Lombaert S. (2009) Design and synthesis of substituted nicotinamides as inhibitors of soluble epoxide hydrolase. Bioorg. Med. Chem. Lett. 19: 5864-8 [PMID:19758802]

113. Tholander F, Muroya A, Roques BP, Fournié-Zaluski MC, Thunnissen MM and Haeggström JZ. (2008) Structure-based dissection of the active site chemistry of leukotriene A4 hydrolase: implications for M1 aminopeptidases and inhibitor design. Chem. Biol. 15: 920-9 [PMID:18804029]

114. van Diepen JA, Jansen PA, Ballak DB, Hijmans A, Rutjes FP, Tack CJ, Netea MG, Schalkwijk J and Stienstra R. (2016) Genetic and pharmacological inhibition of vanin-1 activity in animal models of type 2 diabetes. Sci Rep 6: 21906 [PMID:26932716]

115. van Esbroeck ACM, Janssen APA, Cognetta 3rd AB, Ogasawara D, Shpak G, van der Kroeg M, Kantae V, Baggelaar MP, de Vrij FMS and Deng $\mathrm{H}$ et al.. (2017) Activity-based protein profiling reveals off-target proteins of the FAAH inhibitor BIA 10-2474. Science 356: 1084-1087 [PMID:28596366]

116. Wan M, Cravatt BF, Ring HZ, Zhang X and Francke U. (1998) Conserved chromosomal location and genomic structure of human and mouse fatty-acid amide hydrolase genes and evaluation of clasper as a candidate neurological mutation. Genomics 54: 408-14 [PMID:9878243]

117. Wang L, Fan J, Thompson LF, Zhang Y, Shin T, Curiel TJ and Zhang B. (2011) CD73 has distinct roles in nonhematopoietic and hematopoietic cells to promote tumor growth in mice. J. Clin. Invest. 121: 2371-82 [PMID:21537079]

118. Watabiki T, Tsuji N, Kiso T, Ozawa T, Narazaki F and Kakimoto S. (2017) In vitro and in vivo pharmacological characterization of ASP8477: A novel highly selective fatty acid amide hydrolase inhibitor. Eur. J. Pharmacol. 815: 42-48 [PMID:29017758]

119. Wei BQ, Mikkelsen TS, McKinney MK, Lander ES and Cravatt BF. (2006) A second fatty acid amide hydrolase with variable distribution among placental mammals. J. Biol. Chem. 281: 36569-78 [PMID:17015445]

120. Wilensky RL and Macphee CH. (2009) Lipoprotein-associated phospholipase A(2) and atherosclerosis. Curr. Opin. Lipidol. 20: 415-20 [PMID:19667981]

121. Woolford AJ, Day PJ, Bénéton V, Berdini V, Coyle JE, Dudit Y, Grondin P, Huet P, Lee LY and Manas ES et al.. (2016) Fragment-Based Approach to the Development of an Orally Bioavailable Lactam Inhibitor of Lipoprotein-Associated Phospholipase A2 (Lp-PLA2). J. Med. Chem. 59: 10738-10749 [PMID:27933945]

122. Yu QS, Holloway HW, Luo W, Lahiri DK, Brossi A and Greig NH. (2010) Long-acting anticholinesterases for myasthenia gravis: synthesis and activities of quaternary phenylcarbamates of neostigmine, pyridostigmine and physostigmine. Bioorg. Med. Chem. 18: 4687-93 [PMID:20627738]

123. Yuzwa SA, Macauley MS, Heinonen JE, Shan X, Dennis RJ, He Y, Whitworth GE, Stubbs KA, McEachern EJ and Davies GJ et al.. (2008) A potent mechanism-inspired O-GlcNAcase inhibitor that blocks phosphorylation of tau in vivo. Nat. Chem. Biol. 4: 483-90 [PMID:18587388] 